\title{
MODEL PENDAMPINGAN KELUARGA BERBASIS ASESMEN, KONSELING, HOME VISIT DAN INTERVENSI SEBAGAI UPAYA MENUMBUHKAN MOTIVASI BELAJAR ANAK JALANAN DI YAYASAN RUMAH KITA (eRKa) CIPINANG JAKARTA
}

\author{
Adman \\ Universitas Pendidikan Indonesia \\ e-mail : $\underline{\text { adman@upi.edu }}$
}

\begin{abstract}
This study aims to obtain in-depth data and information based on facts and data regarding the family assistance model based on assessment, counseling, home visit and intervention to reconstruct street children's learning motivation organized by Rumah Kita Foundation (eRKa) in Cipinang, DKI Jakarta. This research method is qualitative with a case study approach. Data collection uses field notes, observations, interviews, and documentation. Interviews were conducted with 3 street children, 3 street child parents and 2 street child companions from Rumah Kita Foundation (eRKa) in Cipinang. The results of data processing showed that the implementation of assessment activities, counseling and home visits, as well as interventions, carried out as a model of assistance to the family. Showed good results, namely the emergence of motivation to learn street children so that there is a desire to learn. The conclusion from the results of this study is the process of family assistance based on assessment, counseling and home visits and interventions has been carried out well by facilitators from the Rumah Kita Foundation (eRKa). This family assistance starts after the assistant conducts an assessment to examine the background of street children and their families. The companion can guide the role of parents as primary educators, exemplary examples of worship and obedience to God, good lifestyle, good attitudes and behavior, good relationships with others, and the importance of good education for the future. The counselor also counseled the importance of providing the right motivation, so that the motivation to learn of street children can grow and develop properly. Counseling conducted by eRKa has also helped the learning difficulties of street children. Likewise, home visits and interventions have been carried out well by the facilitator so that optimal learning outcomes can be achieved by street children.
\end{abstract}

Keywords: assessment, counseling, home visit, intervention, assistance.

\begin{abstract}
Abstrak
Penelitian ini bertujuan untuk mendapatkan data dan informasi yang mendalam berdasarkan fakta dan data mengenai model pendampingan keluarga berbasis asesmen, konseling, home visit dan intervensi untuk melakukan rekonstruksi motivasi belajar anak jalanan yang diselenggarakan oleh Yayasan Rumah Kita (eRKa) di Cipinang, DKI Jakarta. Metode penelitian ini adalah kualitatif dengan pendekatan studi kasus. Pengumpulan data menggunakan catatan lapangan, observasi, wawancara dan dokumentasi. Wawancara dilakukan kepada 3 orang anak jalanan, 3 orang tua anak jalanan dan 2 orang pendamping anak jalanan dari Yayasan Rumah Kita (eRKa) di Cipinang. Hasil pengolahan data menunjukan bahwa implementasi aktivitas asesmen, konseling dan home visit serta intervensi yang dilakukan sebagai model pendampingan terhadap keluarga.menunjukan hasil yang baik, yakni munculnya motivasi belajar anak jalanan sehingga terdapat keinginan untuk belajar. Kesimpulan dari hasil penelitian ini adalah proses pendampingan keluarga berbasis asesmen, konseling dan home visit dan intervensi telah dilakukan dengan baik oleh pendamping dari Yayasan Rumah Kita (eRKa). Pendampingan keluarga ini dimulai setelah pendamping melakukan asesmen untuk mencermati latar belakang anak jalanan dan keluarganya. Pendamping telah terbukti mampu memberi arahan tentang peran orang tua sebagai pendidik utama, pemberi contoh teladan tentang ibadah dan ketaatan pada Allah, pola hidup yang baik, sikap dan
\end{abstract}


perilaku yang baik, hubungan pergaulan yang baik dengan sesama, dan pentingnya pendidikan yang baik untuk masa depan mereka. Pendamping juga melakukan konseling tentang pentingnya memberikan motivasi yang baik, sehingga motivasi belajar anak jalanan dapat tumbuh dan berkembang dengan baik. Konseling yang dilakukan eRKa juga telah membantu kesulitan belajar anak-anak jalanan. Demikian pula home visit dan intervensi telah dilakukan dengan baik oleh pendamping sehingga hasil belajar yang optimal dapat dicapai oleh anak-anak jalanan.

Kata Kunci : asesmen, konseling, visit home, intervensi, pendampingan.

\section{PENDAHULUAN}

\section{a. Latar Belakang Masalah}

Anak merupakan anugerah yang diberikan Allah kepada sebuah keluarga. Anak merupakan generasi penerus bangsa yang memiliki peran strategis bagi kemajuan bangsa kedepan. Oleh karena itu, setiap anak harus dibimbing, dilindungi, diberikan kasih sayang, dan diperhatikan secara optimal. Setiap anak secara kodrati memiliki hak, harkat dan martabatnya sebagai manusia yang harus dijaga, dipelihara, dan dijunjung tinggi secara wajar baik secara ekonomi, hukum, politik, sosial, budaya dan segala aspek yang terdapat dalam kehidupan bermasyarakat, berbangsa dan bernegara.

Anak dengan segala potensi yang dimilikinya, menjadikan anak sebagai sumber daya manusia yang berkualitas, dan menjadi pilar utama generasi bangsa di masa depan. Anak yang berkualitas tersebut dicapai karena berfungsinya tugas-tugas utama keluarga, sekolah, lingkungan sekitar, masyarakat dan pemerintah sesuai dengan hak-hak yang seharusnya didapatkan oleh anak. Namun demikian, dalam kenyataannya masih banyak anak yang belum terpenuhi kebutuhan dasar maupun hakhaknya. Misalnya, masih banyak anak yang lalu lalang dan mengais rejeki di jalanan, tanpa adanya perlindungan yang cukup terhadap dampak negatif dari kegiatan pekerjaan tersebut, seperti : kecelakaan, dan atau pelecehan yang dilakukan oleh orang lain.

Belum terpenuhinya hak-hak anak tesebut terjadi karena berbagai sebab, diantaranya dari masalah ekonomi dan masalah rendahnya kesadaran terhadap hak-hak anak dalam keluarga. Meningkatnya jumlah penduduk miskin menjadi penyebab utama meningkatnya sejumlah permasalahan sosial seperti anak jalanan, eksploitasi seksual komersial anak, pencurian, pengangguran dan lain sebagainya. Fragmentasi sosial yang diakibatkan oleh krisis ekonomi menjadikan munculnya masalah sosial anak, salah satunya yang mencolok adalah anak 
jalanan. Kesulitan ekonomi keluarga menjadi penyebab utama munculnya sejumlah anak jalanan ini, khususnya di DKI Jakarta. Data dari Dinas Sosial DKI Jakarta, jumlah anak jalanan pada tahun 2016 berjumlah 14.808 anak, dan pada tahun 2017 menurun menjadi 8.143 anak (https;//m.republika.co.id.tag) Anak jalanan umumnya berasal dari keluarga yang diwarnai pertengkatan, ketidakharmonisan, hadirnya ayah atau ibu tiri, atau keberadaan orang tua yang tidak dapat menjalankan fungsinya. Kondisi lingkungan keluarga yang demikian sangat berpotensi pada munculnya keinginan anak untuk meninggalkan rumah dan turun ke jalan. Umumnya anak jalanan berasal dari keluarga yang ekonominya lemah dan rentan melakukan tindak kekerasan atau pun penelantaran anak. Akhirnya anak turun ke jalan demi untuk mendapatkan uang.

Fenomena munculnya kehidupan anak jalanan di Indonesia merupakan persoalan sosial yang kompleks. Hidup dan berkegiatan di jalanan dan menggunakan jalan untuk tempat tinggal dan berjualan dan juga berkumpul memberi dampak membahayakan keselamatan dirinya dan juga lingkungan sekitarnya. Misalnya munculnya kekerasan fisik atau emosional diantara anak-anak jalanan tersebut. Selain itu, di jalanan mereka dapat terserempet atau jatuh dari angkutan umum.

Menjadi anak jalanan memang bukan pilihan yang menyenangkan. Namun demikian, anak jalanan lebih banyak menghabiskan waktunya di jalanan dibandingkan disekolah/lembaga pendidikan lainnya, sehingga anak-anak tidak termotivasi untuk belajar dengan optimal. Akhirnya motivasi belajar mereka pun menjadi rendah, terutama apabila dibandingkan dengan motivasinya untuk mencari uang di jalanan dengan cara mengamen dan kegiatan lainnya, karena mereka lebih fokus pada upaya untuk bertahan hidup, dan mencari nafkah di jalanan dengan cara hidup di jalanan.

Bagi anak jalanan, kegiatan belajar dan pembelajaran sesungguhnya dapat dilakukan melalui jalur sekolah maupun jalur luar sekolah, seperti di Program Pendidikan Kesetaraan, Homeschooling atau pun Rumah Singgah.Rumah singgah merupakan salah satu alternative solusi kegiatan diluar sekolah untuk menangani masalah rendahnya motivasi belajar dan 
kehidupan anak jalanan. Rumah Singgah ada yang diselenggarakan oleh Lembaga Swadaya Masyarakat (LSM) dan ada pula yang diselenggarakan oleh pemerintah. Di rumah singgah ini lah dilakukan proses pembelajaran, dan pembentukan karakter serta pembekalan latihan kecakapan hidup. Rumah singgah ini diharapkan dapat menjadi wadah pembinaan dan pembelajaran peserta didik, khususnya anak-anak jalanan.

Yayasan eRKa merupakan salah satu satuan pendidikan luar sekolah yang dikelola masyarakat yang berfungsi sebagai Rumah Singgah. Di yayasan eRKa inilah, diberikan pendampingan pada keluarga anak jalanan dengan berbasis pada kegiatan asesmen, konseling, home visit dan intervensi demi untuk melakukan rekonstruksi motivasi belajar anak jalanan. Yayasan Rumah Kita (eRKa) merupakan salah satu lembaga sosial masyarakat dengan memberikan pelayanan kesejahteraan social. Adapun fungsinya adalah untuk memberikan pelayanan berbasis profesi Pekerja Sosial (Social Worker) serta pengabdian pada masyarakat. Organisasi ini bertujuan untuk membangun kontribusi pada pemecahan masalah kesejahteraan sosial, pendidikan,

kesehatan dan perekonomian masyarakat yang berskala kecil dan menengah dengan fokus pada usia anak, khususnya untuk anak jalanan.

Melalui asesmen atau penelusuran latar belakang anak jalanan, melalui pemberian konsultasi, melalui visit home (kunjungan ke rumah keluarga anak jalanan) dan melalui intervensi, diharapkan terjadi rekonstruksi belajar pada anak-anak jalanan khususnya pada motivasi belajar mereka, Peneliti melakukan asesmen pada $R$, yaitu salah satu anak jalanan yang menjadi binaan yayasan Rumah kita. Hasil melakukan asesmen, diketahui bahwa $\mathrm{R}$ mengalami kesulitan belajar, ia mengalami kesulitan membaca pada saat kelas satu dan kelas dua Sekolah Dasar. Hal ini terjadi karena selain ia berasal dari keluarga kurang mampu secara ekonomi dan kurang mendapat perhatian dari keluarganya, ia pun hampir setiap hari lebih banyak menghabiskan waktunya di jalanan, baik mengamen atau pun duduk-duduk dijalanan, dibandingkan dengan kegiatan belajar. $\mathrm{R}$ pernah mengalami tidak naik kelas karena masih belum bisa membaca. 
Akhirnya $\mathrm{R}$ putus asa, dan kemudian membuat keputusan untuk berhenti sekolah, karena ia sangat kesulitan untuk dapat membaca. Setelah berhenti sekolah, $\mathrm{R}$ semakin leluasa untuk melakukan kegiatannya di jalanan, maka ia tetap melanjutkan kegiatannya mengamen dijalanan. Akhirnya motivasi untuk belajar semakin meningkat, sejalan dengan kegiatan $\mathrm{R}$ berikutnya, yaitu : memulung atau mengumpulkan barang-barang bekas yang tidak terpakai lagi tapi masih yang bisa dimanfaatkan apabila di daur ulang. Berkaitan dengan kondisi motivasi belajar $\mathrm{R}$ yang rendah, maka diperlukan rekonstruksi pola pikir $\mathrm{R}$, sehingga ia memiliki motivasi belajar yang lebih baik. Pengembangan dan peningkatan motivasi belajar, khususnya pada kasus anak jalanan bernama $\mathrm{R}$, memerlukan kepedulian, dan keberpihakan setiap orang, sehingga anak jalanan seperti $\mathrm{R}$, memiliki semangat dan harapan untuk belajar dengan baik.

Beberapa menunjukan bahwa belajar secara maksimal itu sangat besar nilainya.Melalui belajar dengan sungguh-sungguh, seseorang dapat memperoleh peningkatan dalam

wawasan, dalam akses yang lebih luas lagi, Jadi belajar sudah jelas tidak akan membuat diri kita merasa rugi, akan tetapi justru kita akan mendapatkan keuntungan yang banyak. Pengalaman menujukan hasil yang efektif dari belajar maksimal. Masing-masing individulah yang nantinya akan mendapatkan pengalaman tersebut. Seperti halnya konseling dan bimbingan belajar yang di adakan di Yayasan erka dimana peserta didiknya adalah anak jalanan yang menjadi bimbingan eRKa. Dalam konseling, hal ini selalu ditanamkan pada $\mathrm{R}$ dan anak-anak jalanan lainnya, agar mereka tumbuh motivasi belajarnya.

Konseling bagi peserta didik merupakan hal penting.Pendidik berusaha untuk mendengarkan semua kesulitan mereka, agar mendapat solusi untuk mengatasi kesulitan mereka. Dari hasil olah data konseling diketahui bahwa anak jalanan itu umumnya mendapat kesulitan belajar, karena mereka tumbuh dan berkembang dengan lingkungan yang memerlukan perhatian, bimbingan dan arahan yang jelas dan terus menerus. . Konseling dilakukan agar peserta didik secara bertahap 
mampu mengenal, memahami tentang materi pembelajaran.

Yayasan Rumah Kita (eRKa) mencoba membantu anak jalanan yang menjadi binaan eRKa untuk lebih mengenal dan memahami tentang pelajaran yang mereka pelajari melalui kegiatan bimbingan belajar. Selain itu bimbingan belajar ini juga bertujuan untuk membuat mereka memahami bahwa belajar itu penting.

Home visit juga dilakukan untuk mendapatkan kebenaran fakta dari informasi yang diperoleh. Melalui home visit, dapat dilihat secara jelas, bagaimana bentuk perhatian orang tua yang dilakukan pada anak jalanan tersebut. Melalui jenis-jenis komunikasi atau bentuk komunikasi apa yang dilakukan orang tua, yang memungkinkan anak jalanan memiliki motivasi belajar yang baik. eRKa juga memberikan pendampingan peran orang tua sebagai pendidik utama, sehingga tanggung jawab, pemberi motivasi dalam bentuk kasih sayang, orang tua memberi pengaruh dan arah terhadap anak-anak. Kegiatan home visit ini diharapkan dapat membuat anak-anak jalanan yang menjadi binaan Yayasan Rumah Kita terbangun motivasi belajarnya. Jika motivasi belajar mereka sudah terbangun, nilai pelajaran mereka pun akan menjadi lebih baik.

Hak anak untuk mendapatkan perlindungan dari kekerasan dan deskriminasai dijamin oleh UndangUndang,dan dalam Pasal 23 ayat 1 menegaskan bahwa orang tua dan keluargalah yang bertanggung jawab memenuhi hak anak karena hal tersebut menjadi kewajiban orang tua dan keluarga. Orang tua, wali bertanggung jawab terhadap hak-hak anak, begitu pun dengan pendidikan anak menjadi tanggung jawab penuh orang tua. Selain itu orang tua bertanggung jawab membesarkan dan mendidik serta memberikan perlindungan kepada anak karena hal tesebut merupakan kewajiban orang tua. Pendekatan keluarga melalui home visit juga dilakukan eRKa demi untuk memotivasi L yang menjadi anak jalanan tersebut. Demikian pula intervensi dilakukan sebagai salah satu pilihan yang dipandang efektif sebagai solusi untuk menangani masalah anak terlantar khususnya anak jalanan, dengan didasari oleh beberapa alasan.

Pertama, keluarga mempunyai peranan yang sangat besar bagi kehidupan setiap anak, bahkan sejak di 
dalam kandungan, sampai kemudian memasuki masa kanak-kanak, remaja, dewasa awal, dewasa akhir disepanjang kehidupannya. Proses untuk membangun kepribadian dan termasuk semangat belajar anak sangat dipengaruhi oleh peran keluarga khususnya orang tua dalam mendidik dan memberikan contoh yang baik pada anak-anaknya.

Kedua, keluarga juga beran penting dalam membangun kesadaran anak untuk menumbuhkan rasa sosialnya dengan lingkungan sekitarnya, baik lingkungan keluarga mupun lingkungan masyarakat yang lebih luas.

Ketiga, keluarga merupakan tempat menumbuhkan rasa kasih dan sayang diantara sesama, baik sebagai anggota keluarga maupun sebagai bagian dari lingkungan masyarakat yang lebih luas. Keempat, keluarga sebagai tempat memenuhi kebutuhan fisik maupun emosional. Sebagai bagian dari organisasi masyarakat, keluarga menjadi tempat untuk memenuhi segala kebutuhan anak baik fisik maupun mental dan emosional. Kelima, keluarga juga menjadi bagian dari faktor utama masalah keterlantaran, pada saat bersamaan dapat menjadi sumber pemecahan. Pendampingan melalui

asesmen, konseling, home visit dan intervensi tidak hanya dilakukan oleh seorang pendamping saja, melainkan juga oleh keluarga, teman serta masyarakat sekitar tempat tinggal anak jalanan sehingga mereka merasa termotivasi untuk merubah perilaku belajarnya, sehingga pada akhirnya motivasi belajarnya menjadi lebih baik.

Model Penanganan Anak Jalanan Berbasis Masyarakat (Community based) adalah salah satu model penanganan anak jalanan yang secara mamadai. Ketiga, keluarga selain sebagai faktor utama masalah keterlantaran, pada saat bersamaan dapat menjadi sumber pemecahan. Model Penanganan Anak Jalanan Berbasis Masyarakat (Community based) adalah salah satu model penanganan anak jalanan yang menerapkan strategi pengembalian anak kepada keluarganya dan mencegah anak-anak menjadi anak jalanan. Tujuan model ini adalah meningkatkan kemampuan keluarga dan anggota masyarakat dalam melindungi, mengasuh dan memenuhi kebutuhan anak-anak. Tumbuhnya motivasi belajar anak jalanan ini akan menjadikan semangat belajar yang baik, dan pada 
akhirnya hasil belajar yang optimal dapat dicapai anak jalanan.

Posisi keluarga sangat strategis sebagai bagian dari upaya pelayanan anak terlantar, karena keluarga dapat menjadi sumber pemecahan keterlantaran anak. Maka pelayanan anak terlantar tidak hanya bertumpu dan terbatas pada sistem Panti yang telah sekian lama dikembangkan tetapi juga memberikan peluang kepada keluarga untuk melibatkan diri secara proaktif.

Yayasan Rumah Kita (eRKa) menggunakan pelayanan berupa pendampingan berbasis keluarga sebagai upaya untuk memecahkan masalah kesejahteraan anak melalui kemampuan dan kekuatan keluarga. Sasaran program pendampingan ini adalah orang tua anak jalanan yang menjadi binaan Yayasan Rumah Kita (eRKa). Hal ini berarti bahwa pendampingan, baik melalui asesmen, konseling, home visit dan intervensi serta bimbingan belajar merupakan suatu usaha yang penuh kesungguhan dilakukan terhadap para siswa atau peserta didik yang mengalami kesulitan belajar dalam suatu kegiatan belajar tertentu. Melalui strategi pendampingan berbasis keluarga ini diharapkan dapat menguatkan fungsi keluarga itu sendiri sebagai pencegahan agar anak tidak turun kembali ke jalan. Kembalinya peran orang tua dalam memberikan hak anaknya untuk mendapatkan pendidikan mungkin dapat membangun motivasi belajar anak baik disekolah, rumah maupun dimanapun dan anak pun dapat terus berprestasi.

Masalah yang muncul didalam beberapa penelitian menunjukan bahwa pendampingan itu seringkali bersifat cenderung bersifat menggurui sehingga tidak berhasil membangun motivasi anak, termasuk motivasi belajarnya. Oleh karena itu diperlukan suatu penelitian tentang bagaimanakah model pelaksanaan pendampingan keluarga yang dilakukan dengan melakukan asesmen, konseling, home visit dan intervensi itu diselenggarakan pada anak jalanan yang dikelola oleh yayasan eRKa di Jakarta.

\section{b. Rumusan Masalah}

Berbagai paparan di latar belakang masalah di atas, maka masalah pada penelitian ini dirumuskan sebagai berikut : Bagaimanakah model pendampingan keluarga yang berbasis asesmen, konseling, home visit dan intervensi itu diselenggarakan pada anak 
jalanan yang dikelola oleh yayasan eRKa di Jakarta.

\section{KAJIAN TEORI}

\section{a. Hakikat Pendidikan Luar Sekolah}

Pendidikan luar sekolah merupakan salah satu dari tiga jenis pendidikan sebagaimana tercantum dalam Undang-Undang No. 20 Tahun 2003. Suatu aktivitas dapat dikatakan sebagai pendidikan luar sekolah apabila diselenggarakan dan dibutuhkan oleh masyarakat dalam rangka mendukung pendidikan sepanjang hayat (life long education). Pendidikan luar sekolah adalah pendidikan yang dirancang untuk membelajarkan warga belajar agar mempunyai jenis keterampilan atau pengetahuan serta pengalaman yang dilaksanakan diluar jalur pendidikan formal (persekolahan). Pernyataan tersebut mengemukakan bahwa pendidikan luar sekolah pada dasarnya dibutuhkan atas dasar kebutuhan masyarakat atas ruang lingkup pembelajaran tertentu.

Tujuan pendidikan luar sekolah agar menciptakan individu yang mampu melihat permasalahan-permasalahan sekitar dan bertanggung jawab untuk memperbaiki kehidupannya sendiri sehingga mampu mengatasi permasalahan-permasalahan tersebut dengan memanfaatkan potensi yang ada didalam dirinya dan lingkungan sekitarnya.

\section{b. Konsep Pendampingan Keluarga}

Newsletter P2TP2A Istilah "pendampingan" (edisi IV/Vol 1/2007 Jakarta) dalam sistem hukum di Indonesia baru dikenal setelah berlakunya Undang-Undang Nomor. 23 Tahun 2003 tentang Perlindungan Anak dan Undang-Undang Nomor. 23 Tahun 2004 tentang Penghapusan Kekerasan dalam Rumah Tangga (UU PKDRT). Pendampingan menurut pasal 1 ayat 12 Undang-Undang Perlindungan Anak adalah "pekerja sosial yang mempunyai kompetensi profesional dalam bidangnya".

Albert R. Roberts, Gilbert J. Greene (2008: xiii) Pekerja sosial adalah suatu profesi yang dilakukan secara internasional dan mempunyai jaringan organisasi praktik dan pendidikan internasional. Pekerja sosial adalah yang pertama dalam pelayanan manusia yang memberikan fokus pada manusia dalam lingkungan sebagai suatu pradigma 
dalam melakukan asesmen dan perubahan.

Pendampingan keluarga dalam penelitian ini adalah suatu cara atau usaha dalam melakukan kegiatan untuk memberikan pembinaan, pengajaran, pengarahan kepada individu atau kelompok yang bersangkutan dalam upaya memberikan saran, dan bantuan berupa alternatif pemecahan masalah kepada rakyat dalam proses perubahan sosial dengan mengembangkan proses interaksi dan komunikasi.

\section{c. Hakikat Keluarga}

Menurut Undang-Undang Nomor 23 Tahun 2002 tentang Perlindungan Anak, "Keluarga adalah unit terkecil dalam masyarakat yang terdiri dari suami istri, atau suami istri dan anaknya, atau ayah dan anaknya, atau ibu dan anaknya, atau keluarga sedarah dalam garis lurus keatas atau kebawah sampai dengan derajat ketiga”. Dengan demikian keluarga sangat berperan penting bagi kehidupan setiap anak.

Keluarga memiliki peran penting terutama dalam :

1. Membangun pondasi agama

2. Keluarga sebagai pondasi sosial budaya
3. Keluarga sebagai tempat menumbuhkan rasa kasih dan sayang

4. Keluarga sebagai tempat berlindung

5. Keluarga sebagai pondasi pendidikan reproduksi

6. Keluarga sebagai agen sosialisasi pendidikan

7. Keluarga sebagai pondasi pendidikan ekonomi

8. Keluarga sebagai pondasi pendidikan lingkungan

9. Keluarga sebagai tempat memenjuhi kebutuhan fisik m,aupun emosional (https://guruppkn.com.peran keluarga) diunduh pada tanggal 30 September 2019.

\section{d. Peran Orang Tua}

Edy Suharsono (1994: 3) peran dapat dijelaskan melalui beberapa cara, yaitu:

1) Penjelasan historis menyebutkan konsep peran dipinjam dari kalangan drama atau teater yang hidup subur pada zaman Yunani atau Romawi artinya peran menunjukkan pada karakterisasi yang disandang untuk dibawakan oleh seorang aktor dalam sebuah pentas drama. 
2) Peran dikatakan dengan ilmu sosial sebagai suatu fungsi yang dibawakan oleh seseorang ketika menduduki suatu karekterisasi (posisi) dalam struktur sosial.

3) Peran adalah suatu batasan yang dirancang karena adanya peranan orang lain.

Peran orang tua yang secara langsung bertanggung jawab terhadap perkembangan peserta didik dan juga dapat memberikan motivasi belajar sehingga dapat meningkatkan hasil belajar peserta didik.

Didalam keluarga, orang tua harus berperan sebagai guru. Guru adalah pendidik, yang menjadi tokoh panutan, dan identifikasi bagi peserta didik dan lingkungannya. Oleh karena itu orang tua, seyogyanya mampu memiliki tanggung jawab, wibawa, mandiri dan disiplin, cukup memahami kepribadian dan kompetensi yang memadai untuk mengembangkan potensi yang di miliki mereka. Hal ini menjadi tugas utama pendamping dari eRKa dalam melakukan pendampingan pada keluarga/ orang tua anak jalanan. Pendamping eRKa mendamping dan sekaligus meyakinkan tentang peran utama keluarga dengan meyakinkan bahwa keluarga berperan penting dalam mendidik anak jalanan. Dari pergaulan anak, keluarga mengikuti agar mereka tidak salah bergaul yang memungkinkan mereka salah arah. Dalam keluarga, keluarga juga berperan mendidik dan memberi teladan dengan penuh cinta kasih dan tanggung jawab. Hal ini sejalan dengan konsep Ki Hajar Dewantara (1950) dengan konsep Taman Siswanya, yaitu "mengembangkan suatu cara pendidikan yang tersebut didalam Among dan bersemboyan 'Tut Wuri Handayani' (mengikuti sambil mempengaruhi). Arti Tut Wuri aialah mengikuti, namun maknanya ialah mengikuti perkembangan sang anak dengan penuh perhatian berdasarkan cinta kasih dan tanpa pamrih, tanpa keinginan menguasai dan memaksa, dan makna Handayani ialah mempengaruhi dalam arti merangsang, memupuk, membimbing, memberi teladan agar sang anak mengembangkan pribadi masing-masing melalui disiplin pribadi”.

\section{e. Motivasi Belajar}

Sardiman A.M (2011: 75)

Motivasi belajar adalah faktor psikis yang bersifat non-intelektual. Peranannya yang khas adalah dalam hal penumbuhan gairah, merasa senang dan 
semangat untuk belajar. Siswa yang memilki motivasi kuat, akan mempunyai banyak energi untuk melakukan kegiatan belajar.

Motivasi adalah upaya untuk mengebangkan sikap dan perilaku agar dapat mencapai tujuan tertentu.

Teori motivasi dapat dipelajari dari teoriteori motivasi dapat dibagi kedalam tiga kategori, yaitu (1) teori isian (kepuasan hati); (2) teori proses; (3) teori pengukuhan (Teori penyokongan). Hutabarat (1997: 11) membagi motivasi terbagi atas dua macam, yaitu: motivasi ekstrinsik dan motivasi intrisik. Motivasi intrisik adalah motivasi yang berasal dari sendiri dan motivasi ekstrinsik dari luar diri. Belajar dalam pandangan Gagne sebagaimana dikutip Grounlund, Nourman E dan Linn, Robert L (1985) adalah seperangkat proses kognitif yang mengubah sifat stimulasi dari lingkungan menjadi beberapa tahapan pengolahan informasi yang diperlukan untuk memperoleh kapabilitas yang baru. Kapabilitas inilah yang disebut hasil belajar. Berarti belajar itu menghasilkan berbagai macam tingkah laku yang berlain-lainan, seperti pengetahuan, sikap, keterampilan, kemampuan, informasi, dan nilai.
Berbagai macam tingkah laku yang berlain-lainan inilah yang disebut kapabilitas sebagai hasil belajar.

Selanjutnya Gagne dan Briggs dalam Grounlund, Nourman E dan Linn, Robert L (1985) menjelaskan ada lima ategori kapabilitas hasil belajar, yaitu keterampilan intelektual (intellectual skills), strategi kognitif (cognitive strategies), informasi verbal (verbal information), keterampilan motorik (motor skills), dan sikap (atitudes).

Dapat disimpulkan bahwa motivasi belajar adalah semangat atau gairah untuk belajar, sehingga pada akhirnya dapat menghasilkan ilmu pengetahuan, sikap, perilaku, keterampilan, kemampuan, informasi, dan seperangkat tata nilai.

Adapun motivasi pendamping dari yayasan eRKa dalam menjalankan tugasnya adalah sebagai berikut :

1. Keagamaan. Pendamping eRKa melakukan sesuatu bagi sesamanya sebagai amal saleh atau perbuatan baik, dengan harapan mendapatkan balasan dari Tuhan.

2. Rasa kesetiakawanan yang tertanam dalam hati sanubari. Pendamping eRKa berbuat sesuatu karena 
dorongan hati untuk berbuat sesuatu bagi kemanusiaan.

3. Kebutuhan sosial. Pendamping eRKa aktif di organisasi, melakukan sesuatu karena dorongan untuk menjalin hubungan sesama manusia sebab manusia merupakan makhluk sosial.

4. Aktualisasi diri. Pendamping eRKa melakukan sesuatu karena dia ingin mengekspresikan dirinya, ingin berprestasi, berbuat terbaik.

\section{f. Definisi Pembelajaran}

Syaiful Sagala (2012: 61)

Pembelajaran adalah proses interaksi peserta didik dengan pendidik dan sumber belajar. Belajar merupakan proses terjadinya perubahan tingkah laku sebagai hasil dari pengalaman yang dikendalikan maupun pengalaman yang tidak dikendalikan. Pembelajaran merupakan proses kegiatan belajar yang dikelola pendidik, sehingga membuat seorang anak jalanan menjadi belajar, sehingga ia dapat meningkatkan penguasaan dan pengembangan yang baik terhadap materi pembelajaran. Target belajar dapat diukur melalui perubahan sikap dan kemampuan siswa melalui proses belajar untuk mencapai tujuan yang telah direncanakan sebelumnya dan diharapkan dapat dimiliki oleh siswa serta dipraktekkan dan diterapkan dikehidupannya setelah mereka melakukan proses pembelajaran tersebut. Penerapan pembelajaran dapat dilakukan oleh peserta didik bila seorang tutor menggunakan strategi pembelajaran yang tepat dalam menyampikan materi pembelajaran sehingga akan memudahkan peserta didik menerima dan memahami materi pembelajaran, yang pada akhir tujuan pembelajaran dapat dikuasainya di akhir kegiatan belajar.

\section{g. Definisi Hasil Belajar}

Hasil belajar dapat diartikan sebagai kemampuan yang dicapai setelah mengikuti proses pembelajaran yaitu perubahan perilaku peserta didik yang dapat diamati dan kemampuan peserta didik yang berupa keterampilan sebagai akibat latihan dan pengalaman. Kegiatan pendampingan pada keluarga/orang tua anak jalanan merupakan kegiatan yang dilakukan untuk membimbing orang tua tentang bagaimna mendidik dan membimbing anak jalanan di rumah, juga didalam kehidupan bermasyarakat. Pembelajaran / pendampingan pada 
orang tua anak jalanan, yang diarahkan pendamping dari eRKa menumbuhkan tiga aspek utama pada orang tua anak jalanan ini

yaitu pengetahuan, keterampilan dan sikap untuk menumbuhkan motivasi belajar anak jalanan agar mereka semangat belajar sehingga memiliki pengetahuan, sikap dan keterampilan untuk masa depannya.

\section{h. Definisi Anak Jalanan}

Anak jalanan menurut PBB adalah anak yang sebagian besar menghabiskan waktunya di jalanan untuk bekerja, bermain dan beraktifitas lain. Anak jalanan dijalanan karena dicampakkan atau tercampakkan dari keluarga yang tidak mampu menanggung beban kemiskinan dan kehancuran keluarganya. Umumnya anak jalanan bekerja sebagai pengasong, pemulung, pengamen, tukang semir, pelacur anak dan pengais sampah. Tidak jarang menghadapi resiko kecelakaan lalu lintas, pemerasan, perkelahian dan kekerasan lain.

\section{KERANGKA BERFIKIR}

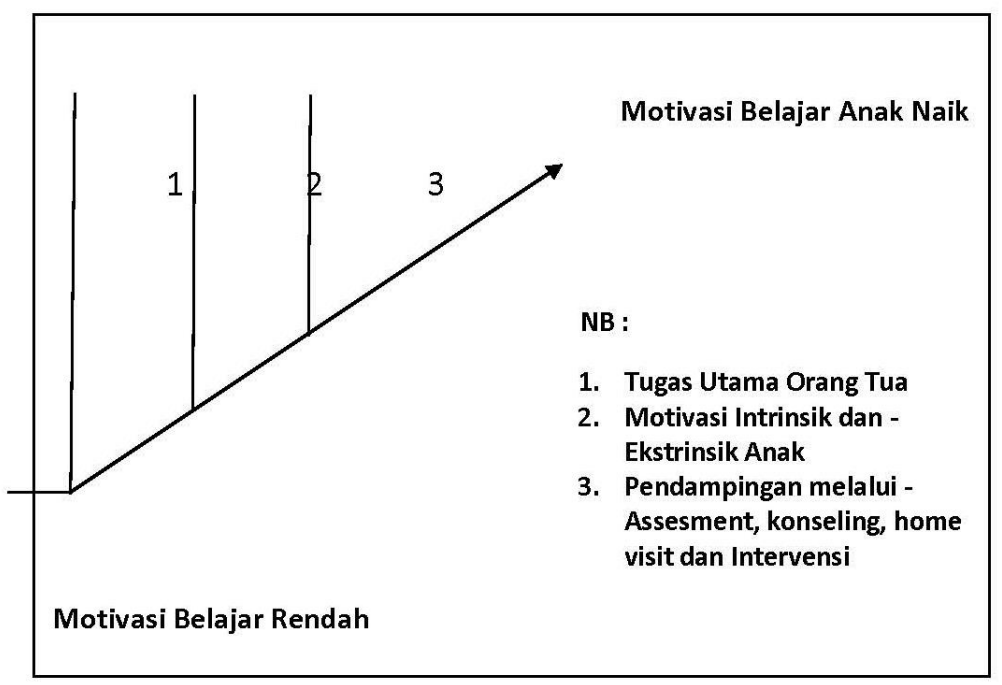

\section{Gambar 1. Kerangka Berfikir}

\section{METODOLOGI PENELITIAN}

Metode yang digunakan adalah metode penelitian kualitatif. Data kualitatif merupakan sumber deskripsi yang luas yang didapat dari subjek penelitian dan memuat penjelasan mengenai proses-proses yang terjadi dalam lingkup setempat. Deskripsi yang 
nantinya akan dihasilkan adalah gambaran tentang bagaimana kegiatan pendampingan berbasis keluarga dalam membangun motivasi belajar anak jalanan ditinjau dari aspek pembelajaran yang dilakukan oleh Yayasan Rumah Kita (eRKa), di Cipinang.

Teknik atau pendekatan yang digunakan dalam penelitian ini adalah pendekatan studi kasus (incase study) yaitu dengan berusaha menguraikan dan menjelaskan berbagai sudut pandang individu yang menjadi objek penelitian mengenai pendampingan berbasis keluarga dalam membangun motivasi belajar anak jalanan.

\section{HASIL DAN PEMBAHASAN}

Setelah dilakukan pengolahan data dapat dipaparkan tentang kondisi rekonstruksi motivasi belajar anak jalanan pada penelitian ini adalah sebagai berikut :

Tabel 1. Rekonstruksi Motivasi Belajar

\begin{tabular}{|c|c|c|c|c|c|c|c|c|c|}
\hline No & Informan & $\begin{array}{l}\text { Infor- } \\
\text { man } 1\end{array}$ & $\begin{array}{l}\text { Infor- } \\
\text { man } 2\end{array}$ & $\begin{array}{l}\text { Infor- } \\
\operatorname{man} 3\end{array}$ & $\begin{array}{l}\text { Infor- } \\
\text { man } 4\end{array}$ & $\begin{array}{l}\text { Infor- } \\
\text { man } 5\end{array}$ & $\begin{array}{l}\text { Infor- } \\
\text { man } 6\end{array}$ & $\begin{array}{l}\text { Infor- } \\
\text { man } 7\end{array}$ & $\begin{array}{l}\text { Infor- } \\
\text { man } 8\end{array}$ \\
\hline & Data & $\begin{array}{l}\text { Pendam- } \\
\text { ping I }\end{array}$ & $\begin{array}{l}\text { Pendam- } \\
\text { ping II }\end{array}$ & $\begin{array}{l}\text { Anak } \\
\text { jalanan } \\
\text { A }\end{array}$ & $\begin{array}{l}\text { Anak } \\
\text { jalanan } \\
\text { C }\end{array}$ & $\begin{array}{l}\text { Anak } \\
\text { jalanan } \\
\text { L }\end{array}$ & $\begin{array}{l}\text { Orang } \\
\text { tua } W \\
\text { (AR) }\end{array}$ & $\begin{array}{l}\text { Orang } \\
\text { tua OL } \\
\text { (EB) }\end{array}$ & $\begin{array}{l}\text { Orang } \\
\text { tua } \mathrm{R} \\
(\mathrm{WB})\end{array}$ \\
\hline 1 & Usia & 24 thn & 28 thn & 9 thn & 8 thn & 9 thn & 51 thn & 55 thn & 53 thn \\
\hline 2 & Jenis Kelamin & $\mathrm{L}$ & $\mathrm{L}$ & $\mathrm{L}$ & $\mathrm{L}$ & $\mathrm{L}$ & $\mathrm{P}$ & $\mathrm{P}$ & $\mathrm{P}$ \\
\hline 3 & Daerah Asal & Jakarta & Jakarta & Jakarta & Jakarta & Jakarta & Jakarta & Jakarta & Jakarta \\
\hline 4 & Pendidikan & $\begin{array}{l}\text { S1 UPI } \\
\text { Bandung, } \\
\text { S2 UPI } \\
\text { Bandung }\end{array}$ & S1 UNJ & $4 \mathrm{SD}$ & $5 \mathrm{SD}$ & $3 \mathrm{SD}$ & $\begin{array}{l}\text { Tamat } \\
\text { SD }\end{array}$ & $\begin{array}{l}\text { Tamat } \\
\text { SD }\end{array}$ & $\begin{array}{l}\text { Tidak } \\
\text { sekolah }\end{array}$ \\
\hline
\end{tabular}

Pendidikan di dalam keluarga yang dilakukan oleh AR dan EB sebagai orang tua, terjadi setelah kedua orang tua anak jalan an tersebut mendapat asesmen,konseling,home visit dan intervensi dari para pendamping dari yayasan eRKa. Tumbuhnya berbagai kesadaran pada AR,dan EB dan WB, juga rasa tanggung jawab dan rasa kasih sayang sebagai orang tua yang harus mendidik dan memberi teladan pada anak, muncul setelah penamping menempuh pendekatan pada ketiga keluarga tersebut dengan basis asesmen, konseling, home visit dan intervensi dari para pendamping dari yayasan eRKa. 
Pendampingan terhadap keluarga, informasi dan penananaman keyakinan menjadikan keluarga/orang tua anak tentang manfaat ilmu pengetahuan yang jalanan melakukan pendidikan yang harus menjadi bekal untuk masa depan optimal dalam memberikan semangat anak-anak jalanan tersebut. belajar pada anak-anaknya, yang pada hakekatnya adalah juga siswa yang masih bersekolah di SD.

Uraian diatas mengisyaratkan betapa pentingnya peran pendamping dalam membangun kesadaran tentang dasar-dasar pendidikan bahwa di rumah harus dibangun praktek pendidikan baik berupa nasihat maupun rangkaian contoh atau keteladanan, fakta tentang betapa pentingnya motivasi belajar untuk mendapatkan ilmu pengetahuan bagi hidup anak di masa depan. Dalam pendampingan Tim pendamping juga memberikan keyakinan bahwa dalam pendidikan di keluarga juga harus bermuatan nilai-nilai etika, norma-norma yang memungkinkan anak dapat meresapinya dan mempraktekannya. Melalui asesmen, konseling, home visit dan intervensi, tim pendamping juga menekankan tentang pentingnya membangun semangat untuk mencari ilmu atau motivasi belajar tersebut, sesuai tuntutan agama dan penting untuk masa depan anak. Dalam posisi ini tim pendamping memberikan bantuan, Pendampingan ini dilakukan untuk membangun kemampuan atau kemandirian dalam tahap awal pada orang tua anak jalanan dengan pendekatan dialog, dan bersifat personal. Pendamping juga melakukan konseling tentang pentingnya memberikan motivasi yang baik, sehingga motivasi belajar anak jalanan dapat tumbuh dan berkembang dengan baik. Konseling yang dilakukan eRKa juga telah membantu kesulitan belajar anak-anak jalanan. Demikian pula home visit dan intervensi telah dilakukan dengan baik oleh pendamping sehingga hasil belajar yang optimal dapat dicapai oleh anakanak jalanan.

\section{PENUTUP}

\section{a. Kesimpulan}

Berdasarkan data yang diperoleh dari hasil penelitian dapat disimpulkan bahwa: Pendampingan yang diberikan Yayasan Rumah Kita (eRKa) kepada keluarga/ orang tua anak jalanan, terutama dilakukan melalui langkahlangkah asesmen, konseling, home visit 
dan intervensi. Pendampingan ini memberikan/membekali para orang tua anak jalanan dengan berbagai informasi mengenai pentingnya peran orang tua dalam menunaikan tugas sebagai orang tua pada anak-anaknya dengan penuh tanggung jawab, kasih sayang dan kepekaan yang tinggi demi untuk membangun masa depan mereka. Khususnya melalui upaya menumbuhkan semangat belajar mereka.

Pendamping juga menegaskan pentingnya memenuhi kebutuhan atau hak-hak anak, terutama berkaitan dengan pendidikan, dengan dilakukan asesmen, konseling dan pemberian intervensi sebagai upaya untuk menguatkan fungsi keluarga anak jalanan tersebut. Untuk melihat keberhasilan pendampingan atau evaluasi yang dilakukan melalui pengamatan saat kunjungan rumah (home visit), indikator keberhasilan pendampingan yakni terjadinya perubahan tingkah laku pada klien yang didampingi.

\section{b. Implikasi}

Beberapa implikasi dari penelitian ini adalah: perlunya membangun pendekatan yang kondusif dengan keluarga/ orang tua anak jalanan dan anak jalanan itu sendiri, sehingga keluarga dan anak jalanan merasa merasa nyaman dan yakin terhadap niat baik dan tujuan mulia dari tim pendamping. Pada sisi lain hal ini juga sangat penting bagi pendamping agar dapat menunaikan tugas-tugasnya secara lebih kondusif, sistimatis dan sesuai dengan tujuan utama pendampingan, yaitu mendampingi keluarga agar dapat memenuhi tugas utama sebagai orang tua, khususnya dapat memotivasi belajar anak jalanan sehingga mereka memiliki semangat belajar yang tinggi dan pada akhirnya memiliki masa depan yang lebih baik.

Proses pendampingan yang dilakukan tim pendamping dari yayasan berikan oleh Yayasan Rumah Kita kepada keluarga/orang tua anak jalanan sudah dilakjukan dengan baik, melakukan kegiatan yang beragam dan sistimatis, yakni melalui asesmen, konseling, kunjungan rumah (home visit) dan intervensi.

\section{c. Saran}

Beberapa saran yang dapat disampaikan dari hasil penelitian ini adalah sebagai berikut :

1) Kepada Yayasan Rumah Kita (eRKa), langkah yang sudah kondusif ini seyogyanyha 
Jurnal Parameter Volume 31 No. 1

DOI : doi.org/10.21009/parameter.311.02

P-ISSN : 0216-261X E-ISSN : 2620-9519

ditertuskan,demi membangun semangat nbelajar pada anakanak jalanan,khususnya melalui

2) langkah-langkah asesmen, konseling, kunjungan rumah (home visit) dan intervensi.

3) Kepada tim Pendamping, tugas pengabdian ini seyogyanya terus dikembangkan dengan lebih baik lagi, misalnya ditingkatkan dengan langkah evaluasi dari setiap langkah pendampingan, misalnya evaluasi program asesmen, evaluasi program konseling, evaluasi program home visit dan evaluasi program intervensi.

\section{DAFTAR PUSTAKA}

Djohar. 2002. Pendidikan Strategik: Alternatif Untuk Pendidikan Masa Depan, Yogyakarta: LESFI

Furchan, Arief. 2000. Pengantar Penelitian Dalam Pendidikan, Surabaya: Usaha Nasional

Galtung, Johan. 2003. Studi Perdamaian: Perdamaian dan Konflik, Pembangunan dan Peradaban, Surabaya: Pustaka Euraka
Handbook. 2007. Ilmu dan Aplikasi Pendidikan Bagian ke 2 Ilmu Pendidikan Praktis), Bandung: Tim Pengembang Ilmu Pendidikan FIP UPI

Harry, Hikmat. 2001. Strategi Pemberdayaan Masyarakat. Bandung: Humaniora Utama Press

Mark K, Smith, dkk. 2009. Teori Pembelajaran dan Pengajaran: Mengukur Kesuksesan Anda dalam Proses Belajar dan Mengajar Bersama Psikolog Pendidikan Dunia. Jogjakarta: Mirza Media Pustaka

Mulyana, Deddy. 2001. Metodologi Penelitian Kualitatif. Bandung: Remaja Rosdakarya

Hartiningsih, Maria. 2006. Healing, Gender and Peace (Upaya Mencari Perdamaian), Jakarta: P3i NZAID

Hosfiar, Hervy. 2008. Naskah BP3LS, Meteodelogi Belajar Orang Dewasa, Jakarta: PP3LS

Komisi Nasional Indonesia. 2011. UNESCO dan Kebudayaan Perdamaian Memajukan Suatu Gerakan Global, Jakarta: UNESCO 
Jurnal Parameter Volume 31 No. 1

DOI : doi.org/10.21009/parameter.311.02

P-ISSN : 0216-261X E-ISSN : 2620-9519

Lunandi, 1984. Andragogi, Bandung:

Angkasa

Marzuki, Saleh, Pendidikan Non Formal

Dimensi Dalam Keaksaraan

Fungsional Pelatihan dan

Andragogi, Bandung: PT

Remaja Rosdakarya
Staton, F. Thomas. 1996. Cara Membangun Belajar Sukses, Metode Pengajaran Modern Dalam Pendidikan Orang Dewasa. Jakarta: Rosdakarya

Sudjana, Nana. 2004. Dasar-Dasar Proses Belajar Mengajar. Bandung: Sinar Baru 